\title{
ANALISIS KINERJA PEGAWAI PADA DINAS PEKERJAAN UMUM PROVINSI SULAWESI BARAT
}

\author{
Analysis of Employee Performance in Public Works Office of West Sulawesi Province \\ Yuliana K. Manengkey ${ }^{1}$, Imran Ismail ${ }^{2}$, Nurkaidah ${ }^{2}$ \\ ${ }^{1}$ Dinas Pekerjaan Umum, Sulawesi Barat \\ ${ }^{2}$ Program Studi Ilmu Administrasi Negara, Program Pascasarjana, Universitas Bosowa \\ Email: yuliana.mmj88@gmail.com \\ Diterima: 25 Agustus 2020 \\ Dipublikasikan: 07 Desember 2020
}

\begin{abstract}
ABSTRAK
Aparatur Sipil Negara (ASN) merupakan asset pemerintah yang sangat berharga yang harus dikelola dengan baik oleh pemerintah itu sendiri agar dapat memberikan kontribusi yang optimal. ASN merupakan salah satu sumber daya manusia yang dimiliki oleh pemerintah dalam menjalankan tugas-tugas pemerintahan. Oleh karena itu dibutuhkan pegawai pemerintah yang memiliki kekampuan dan keahlian yang cukup memadai sehingga kinerjanya dapat member pengaruh dalam mewujudkan visi dan misi organisasi pemerintah daerah. Penelitian ini bertujuan untuk menganalisis sistem penempatan pegawai dan sistem pelaksanaan pekerjaan di Dinas Pekerjaan Umum Provinsi Sulawesi Barat. Penelitian ini menggunakan pendekatan deskriptif kualitatif terhadap fenomena kondisi kerja yang ada. Metode penelitian dengan deskriptif kualitatif dipilih karena dianggap sesuai dengan tujuan penelitian dengan maksud menggambarkan dan menginterprestasikan masalah yang berkaitan dengan proses kinerjaA paratur Sipil Negara di lingkup Dinas Pekerjaan Umum dan Penataan Ruang Provinsi Sulawesi Barat. Data diperoleh dengan menggunakan teknik pengumpulan data dengan cara observasi, wawancara, studi kepustakaan, penelusuran data online, dan dokumentasi. Teknik analisis data pada penelitian ini dilakukan secara cermat sesuai dengan metode penelitian ilmiah berdasarkan konsep analisis data yang digunakan pada metode penelitian kualitatif. Hasil penelitian menunjukkan sistem penempatan dan sistem kerja pegawai sangat mempengaruhi kinerja pegawai pada Dinas Pekerjaan Umum dan Penataan Ruang Provinsi Sulawesi Barat dan hal tersebut dipengaruhi oleh peran pemimpin dalam meningkatkan kinerja pegawai menjadi salah satu kunci sukses bagi keberhasilan seluruh organisasi. Berdasarkan hasil analisis diketahui kendala-kendala yang di hadapi pemimpin dalam memotivasi pegawainya yaitu setiap pegawai mempunyai tipe dan karakter yang berbeda-beda dari setiap orang. Upaya memotivasi pegawai agar memiliki skill memang lebih sulit disbanding pegawai yang biasa-biasa saja. Hal tersebut dikarenakan tingkat dan pola piker berbeda antara pegawai yang satu dengan yang lain.
\end{abstract}

Kata Kunci: Kinerja Pegawai, Motivasi, Kepemimpinan, Sulawesi Barat

\begin{abstract}
The State Civil Apparatus (ASN) is a very valuable government asset that must be managed well by the government itself in order to make an optimal contribution. ASN is one of human resources owned by the government in carrying out government tasks. Therefore, we need government employees who have sufficient ability and expertise so that their performance can influence in realizing the vision and mission of local government organizations. This study aims to analyze the employee placement system and the work implementation system in Public Works Office of West Sulawesi Province. This study uses a qualitative descriptive approach to the phenomenon of existing performance conditions. Descriptive qualitative research method was chosen because it was considered in accordance with the purpose of the study with the intention of describing and interpreting issues related to the performance process of the State Civil Apparatus in the scope of Public Works and Spatial Planning Office in West Sulawesi Province. Data were obtained using data collection techniques such as observation, interviews, library research, online data search, and documentation. Data analysis techniques in this study were carried out carefully in accordance with scientific research methods based on the concept of data analysis used in qualitative research methods. The results showed that the placement system and the work system of employees greatly affect the performance of employees in the Department of Public Works and Spatial Planning of West Sulawesi Province and this is influenced by the role of leaders in improving employee performance as one of the keys to for the success of the entire organization. Based on the results of the analysis, it is known that the obstacles faced by leaders in motivating their employees are that each employee has a different type and character from each person. Efforts to motivate employees to have skills are indeed more difficult than ordinary employees. This is because the level and mindset differs from one employee to another..
\end{abstract}

Keywords: Employee Performanc, Motivation, Leadership, Sulawesi Barat

\section{PENDAHULUAN}

Aparatur Sipil Negara (ASN) merupakan aset pemerintah yang sangat berharga yang harus dikelola dengan baik oleh pemerintah itu sendiri agar dapat memberikan kontribusi yang optimal. Pemerintah bukan hanya sebagai abdi negara saja, tetapi juga sebagai abdi masyarakat yang mengayomi dan memberikan pelayanan kepada masyarakat dengan sebaik-baiknya. ASN merupakan salah satu sumber daya manusia yang dimiliki oleh pemerintah dalam menjalankan tugas-tugas 
pemerintahan (UU No. 25 Tahun 2009). Karena itu dibutuhkan pegawai pemerintah yang memiliki kekampuan dan keahlian yang cukup memadai sehigga kinerjanya dapat member pengaruh dalam mewujudkan agenda-agenda pembangunan dalam bernegara.

Kinerja seorang pegawai atau karyawan di dalam suatu organisasi pemerintahan maupun organisasi swasta adalah suatu hal yang penting guna untuk mengukur sejauh mana pencapaian visi dan misi organisasi telah terpenuhi. Namun untuk mencapai hal tersebut dibutuhkan kualitas kemampuan pegawai yang sesuai serta didukung oleh optimalisasi sistem kelembagaan organisasi yang subtansial baik dari segi perangkat maupun aturannya. Karena itu dalam setiap organisasi mendesain sedemikian rupa upaya yang perlu dilakukan agar setiap pegawai atau karyawan dapat memiliki kinerja yang optimal dalam menjalankan kerja-kerja organisasi.

Dalam organisasi pemerintahan kinerja pegawai merupakan salah satu indikator penting yang mesti dicapai oleh instansi pemerintahan mulai dari tingkat pusat sampai didaerah-daerah. Menurut Hasibuan (2012) kinerja adalah suatu hasil kerja yang dicapai seseorang dalam melaksanakan tugas-tugasnya atas kecakapan, usaha, dan kesempatan. Berdasarkan paparan tersebut di atas, kinerja adalah suatu hasil yang dicapai seseorang dalam melaksanakan tugas- tugas yang didasarkan atas kecakapan, pengalaman, dan kesungguhan serta waktu menurut standar dan kriteria yang telah ditetapkan sebelumnya.

Irawan (2000) menyatakan Kinerja (performance) adalah hasil kerja yang konkrit, dapat diamati, dan merupakan hasil kerja yang dicapai oleh pegawai dalam pelaksanaan tugas yang berdasarkan ukuran dan waktu yang telah ditentukan. Dharma (2005) menyatakan bahwa penilaian kinerja didasarkan pada pemahaman, pengetahuan, keahlian, kepiawaian dan perilaku yang diperlukan untuk melaksanakan suatu pekerjaan dengan baik dan analisis atribut perilaku seseorang sesuai kriteria yang ditentukan untuk masing-masing pekerjaan. Simamora (2003) menyatakan bahwa kinerja merupakan suatu persyaratan-persyaratan tertentu yang akhirnya secara langsung dapat tercermin dari output yang dihasilkan baik yang berupa jumlah maupun kualitasnya. Output yang dihasilkan menurut Simamora dapat berupa fisik maupun nonfisik yang menyebutnya berupa karya, yaitu suatu hasil/pekerjaan baik berupa fisik/material maupun nonfisik maupun nonmaterial.

Kemampuan untuk bersaing dengan daerah lainnya yang sudah maju akan semakin sulit jika tidak dibarengi dengan kemampuan aparatur sebagai pegawai pemerintah dalam menjalankan tugas-tugas kepemerintahan. Unitunit kelembagaan dalam tubuh organisasi pemerintahan di Sulbar harus didorong agar lebih produktif dalam menyukseskan agenda- agenda pembangunan daerah.

Pelatihan adalah proses sistematik pengubahan perilaku para pegawai dalam suatu arah guna meningkatkan tujuan-tujuan organisasional. Pelatihan dan pengembangan penting karena keduanya merupakan cara yang digunakan oleh organisasi untuk mempertahankan, menjaga, rnemelihara, pegawai publik dalam organisasi dan sekaligus meningkatkan keahlian para pegawai untuk kemudian dapat meningkatkan produktivitasinya. (Ambar Teguh Sulitiyani \& Teguh, 2003). Spencer and Spencer dalam Sudarmanto (2009) mengatakan, kompetensi merupakan karakteristik dasar perilaku individu yang berhubungan dengan kriteria acuan efektif dan atau kinerja unggul di dalam pekerjaan atau situasi. Dengan kata lain, kompetensi merupakan landasan dasar karakteristik orang dan mengidentifikasikan cara berperilaku atau berpikir, menyamakan situasi, dan mendukung untuk periode waktu cukup lama. Menurut Siagian (1999), kepemimpinan administrasi/manajerial adalah kemampuan dan keterampilan seseorang yang menduduki jabatan sebagai pemimpin satuan kerja atau mempengaruhi perilaku orang lain (bawahannya) untuk berpikir dan bertindak sedemikian rupa sehingga melalui perilaku yang positif ia memberikan tujuan organisasi. Karyadi (1989) mengatakan bahwa tugas pokok seorang pemimpin adalah menghantarkan, mengetahui, mempelopori, memberi petunjuk, mendidik, membimbing dan lain sebagainya. John Millett dalam Sunindhia dan Widiyanti (1998) menyebutkan esensi kompetensi kepemimpinan meliputi: (1) kemampuan melihat dalam hal keseluruhannya; (2) kemampuan untuk mengambil keputusan; (3) kemampuan untuk berani memberikan hak kepercayaan kepada bawahan; dan (4) kemampuan untuk memaksakan kesetiaan.

Banyaknya agenda-agenda pembangunan pemprov Sulbar yang harus dikerjakan oleh Dinas PU mensyaratkan agar organisasi ini dapat bekerja secara efektif dan efisien. Peran serta pegawai sebagai aparatur dalam mengerjakan tugas-tugas pemerintah dalam tubuh organisasi tersebut sangat penting. Namun beberapa hambatan dilapangan yang membuat kinerja para pegawai sangat lamban dan kurang produktif sehingga target-target pencapaian organisasi tidak sesuia dengan yang diinginkan.

Berdasarkan PP Nomor 30 Tahun 2019 tentang Penilaian Kinerja Pegawai Negeri Sipil (PNS), bahwa penilaian kinerja PNS bertujuan untuk menjamin objektifitas pembinaan PNS yang didasarkan pada sistem prestasi dan sistem karir. Penilaian dilakukan berdasarkan perencanaan kinerja pada tingkat individu dan tingkat unit atau organisasi, dengan memperhatikan target, capaian hasil, prilaku aparatur dan manfaat yang dicapai (Nur et. $a l, 2020)$.

Berdasarkan hasil prapenelitian yang dilakukan oleh peneliti pada bulan November tahun 2019 ditemukan beberapa persoalan ditubuh kelembagaan Dinas PU provinsi Sulbar yang membuat kinerja para pegawai kurang produktif. Masalah tersebut antara lain penempatan pegawai dalam menduduki jabatan belum sesuai dengan disiplin ilmu yang dimiliki. Hal ini jelas tidak sesuai dengan tujuan mewujudkan Aparatur Sipil Negara (ASN) yang professional seperti yang 
diamanatkan dalam UU Nomor 5 Tahun 2014 tentang Aparatur Sipil Negara.

Filosofi the right man on the right place (menempatan manusia sesuai keahliannya) adalah merupakan bagian integral dalam upaya melakukan reformasi birokrasi untuk mewujudkan good govermence dan clean government ditubuh pemerintahan melalui reformasi organisasi, manajemen birokrasi dan penguatan sumber daya manusia. Penempatan ASN sesuai dengan keahliannya adalah upaya untuk menghindari penyakit birokrasi yang sering ditemui yaitu jual beli jabatan sehingga dapat mengurangi intervensi politik diera pilkada langsung seperti sekarang ini. Selain itu masalah lainnya adalah masih terdapat pegawai yang menduduki jabatan tertentu belum mengikuti diklat kepemimpinan. Sesuai dengan PP Nomor 101 Tahun 2000 tentang Pendidikan dan Pelatihan Jabatan Pegawai Negeri Sipil bahwa pegawai negeri yang akan menduduki jabatan esalon IV (Kepala Seksi) wajib mengikuti diklat kepemimpinan.

Menurut Siagian yang dikutif dalam Wardani (--) bahwa pentingnya pendidikan dan pelatihan sebagai salah satu investasi dalam bidang sumber daya manusia (Human Investment) yang wajib hukumnya dilaksanakan oleh suatu organisasi apabila organisasi yang bersangkutan ingin bukan saja meningkatkan efesiansi dan efektifitas kinerjanya akan tetapi dalam rangka mempercepat pemantapan perwujudan prilaku organisasi yang diinginkan.

Masalah lainnya adalah di Dinas PUPR provinsi Sulbar adalah pada bidang yang membutuhkan tenaga teknis masih sangat kekurangan tenaga teknis lapangan. Tenaga teknis inilah yang menerjemahkan setiap program pemerintah untuk direalisasikan dilapangan. Salah satu penyebabnya adalah sistem perekrutan pegawai pemerintah sebelum lahirnya UU ASN Nomor 5 Tahun 2014 masih dilakukan secara parsial tanpa spesifikasi. Sehingga jumlah pegawai yang tersedia memenuhi secara kuantitas tetapi tidak dapat menjawab kebutuhan dan beban kerja yang dipertanggungkan. Persoalan-persoalan tersebut diatas sampai sekarang di Dinas PUPR Provinsi Sulbar belum perna dilakukan analisis kinerja pegawai guna untuk menyeleseian masalah-masalah yang ada. Sementara itu beban pekerjaan terus bertambah yang tentu akan menjadi persoalan pegawai.

\section{METODE}

Penelitian ini dilaksanakan pada bulan Juni tahun 2020. Lokasi penelitian di Dinas Pekerjaan Umum provinsi Sulawesi Barat. Penelitian ini menggunakan pendekatan deskriptif kualitatif terhadap fenomena sosial yang sedang terjadi. Data yang digunakan dalam penelitian ini adalah data primer dan data sekunder.

Teknik pengumpulan data dilakukan dengan metode observasi, wawancara, studi kepustakaan (Library Research), dan penelusuran data online. Teknik analisis data pada penelitian ini dilakukan secara cermat dimana data diseleksi mengggunakan teknik analisis data deskriptif yaitu data-data yang telah dihimpun dan dikumpulkan baik primer maupun sekunder, kemudian diambil kesimpulan sebagai jawaban masalah yang diteliti. Pengolahan data diakukan melalui reduksi data, penyajian data dan penarikan kesimpulan dan verifikasi data. Sementara itu kredibilitas data dalam penelitian ini dilakukan melalui perpanjangan pengamatan, meningkatkan ketekunan, triangulasi data, analisis kasus negatif, menggunakan bahan referensi, dan mengadakan member chek.

\section{HASIL DAN PEMBAHASAN}

Sistem Penempatan Pegawai Dinas Pekerjaa Umum dan Perumahan Rakyat Provinsi Sulawesi Barat

Dinas PU sebagai salah instansi yang memiliki beban kerja cukup besar tentu harus didukung dengan pegawai yang mempuni dan sistem pengorganisasian yang produktif. Konsep pengorganisasi instansi PUPR berkaitan dengan Manajemen sumber daya manusia (MSDM). Hal ini dianggap sangat penting dalam rangka meningkatkan kualitas kinerja pegawainya. Karena setiap tenaga kerja ataupun fasilitas pendukung memiliki manfaat dan setiap sumber daya manusia memiliki kemampuan yang berbeda-beda.

Adapun upaya Kepala Dinas PUPR Provinsi Sulbar dalam mengelola manejemen sumber daya manusia dalam meningkatkan kualitas SDM pegawai di lingkungan Dinas PUPR Provinsi Sulbar dilakukan dengan berbagi macam cara. Salah satunya adalah melakukan perencanaan sumber daya manusia yang baik.

Berdasarkan wawancara dengan Kepala Dinas PUPR Provinsi Sulbar (Bpk. Ir. H. Muhammad Aksan, MT) mengatakan bahwa:

"seperti itulah zaman sekarang, persaingan semakin ketat, peluang kerja semakin menyempit, banyak yang lulusan sarjana yang ingin mendaftar di berbagai macam lembaga, institusi, perusahaan dll merasa kesulitan, karena banyaknya pegawai / karyawan yang sudah menempati duluan, akhirnya lulusan baru banyak yang menganggur dan kadang mendaftar / melamar tidak sesuai bidang yang di ambil. Maka dari itu tidak seimbang antara pelamar kerja dan tempat yang buat kerja. Ini juga menjadi sebuah tantangan pekerjaan buat pemerintah, paling tidak bisa menyediakan dan menambah lapangan pekerjaan buat rakyatnya sesuai janjinya. Jadi sekarang, pegangan kita adalah harus sering-sering mendekatkan kepada Allah, berdoa, dan berusaha malam hari bangun sholat tahajut, Insaalah Allah akan mempermudah apa yang kita minta akan menjadi lancar, karena hanya Allah yang bisa mengubah nasib kita baik buruknya, jangan hanya mengandalkan materi. Itulah kunci kita kalau ingin menjadi orang yang berhasil, harus berani berubah".(Wawancara 13 Juni 2020) 
Tujuan utama dari pelatihan dan pengembangan ini adalah untuk mengatasi kekurangan-kekurangan para sumber daya manusia dalam bekerja yang disebabkan oleh kemungkinan ketidakmampuan dalam pelaksanaan pekerjaan, dan sekaligus berupaya membina mereka agar menjadi lebih produktif.

Berdasarkan hasil wawancara dengan Sekretaris Dinas PUPR Provinsi Sulbar (Bpk.Drs.Abdul Halid Aras) mengatakan bahwa:

"Dalam rangka pelatihan dan pengembangan seluruh pegawai telah dilakukan usaha- usaha seperti mengikutsertakan pegawai pada kursus, pendidikan, di adakan diklat, workhshop, seminar dll, untuk menunjang pengetahuan SDM para pegawai, dengan memberikan motivasi kepada pegawai agar kuliah lagi ke jenjang pendidikan yang lebih tinggi/pelatihan kuliah. Dan juga mengadakan studi banding kelembagaan pada lembaga yang dianggap lebih maju". (Wawancara 13 Juni 2020)

Adapun sasaran pelatihan dan pengembangan SDM yang dimaksud berdasarkan hasil wawancara dengan Kasi Kepegawaian Dinas PUPR Provinsi Sulbar (Ibu ST.Sohra,S.Sos.M.Si) adalah sebagai berikut:

"beberapa hal yang kami lakukan dalam mendorong kemampuan para pegawai secara personal yaitu: 1) Meningkatkan produktivitas kerja; 2) Meningkatkan mutu kerja; 3) Meningkatkan ketepatan dalam perencanaan SDM; 4) Meningkatkan moral kerja; 5) Menjaga kesehatan dan keselamata; dan 6) Menunjang pertumbuhan pribadi'. (Wawancara 16 Juni 2020)

Sementara itu berdasarkan hasil wawancara peneliti dengan salah satu pegawai di unit kepegawaian mengatakan bahwa agar seluru bawahan bekerja sesuai dengan yang diharapkan maka penting ada kejelasan dalam bentuk aturan main bagaiman layak sesorang pegawai dalam bekerja.

"harus turan yang jelas bagaimana kami seharusnya bekerja dengan baik sehingga mampu menunjukkan prestasi kerja. Hal tersebut antara lain: 1) Ada aturan-aturan; 2) Menurut regulasi yang ada; dan 3) Dilihat dari disiplin kerja para pegawai'. (Wawancara 16 Juni 2020)

Dalam wawancara yang dilakukan peneliti kepada Kasubag Umum dan kepegawaian Provinsi Sulbar (Ibu Sohra.Sos.M.Si) tentang cara mengetahui atau mengukur kinerja pegawai apakah bisa dikatakan memuaskan kinerjanya.

"beberapa hal yang kita lakukan dalam rangka untuk mengukur kinerja seseorang dalam bekerja, seperti: 1) Tukin (tunjangan kinerja), semua pegawai membuat daftar kinerja pegawai, yang dituangkan sesuai kontrak kerja; 2) Kita bisa melihat pegawai berhasil, dilihat dari SKP ( sasaran kinerja pegawai ), yang dituangkan dalam kontrak kerja, dari atasan sampai bawah; 3) Ada penilaian kinerja; 4) Evaluasi setiap akhir bulan; 5) Memuaskan atau tidak memuaskan itu dilihat dari sikap pegawai itu, pegawai itu dengan bukti fisik. Misalnya: tentang hubungan ke masyarakat itu bisa terjalin dengan baik atau tidak; 6) Melalui penilaian capaian terhadap SKP (sasaran kerja pegawai) setiap akhir tahun; 7) Dari realisasi capaian sasaran kerja pegawai; dan 8) Kepuasan seseorang dapat dilihat dari kinerjanya dalam bekerja di lembaganya". (Wawancara 13 Juni 2020)

Sistem Kerja Pegawai Dinas Pekerjaan Umum dan Perumahan Rakyat Provinsi Sulawesi Barat

Berdasarkan hasil wawancara dengan kepala Dinas PUPR Provinsi Sulbar (Bpk.Ir.H.Muhammad Aksan,MT) mengatakan bahwa ada beberapa hal yang mesti dibuat oleh instansi PU dalam meningkatkan kinerja pegawai.

"ada beberapa hal penting yang seharusnya dibuat oleh instansi PU jika kita ingin meningkatkan kinerja pegawai. Salah satunya adalah berkaitan dengan aturan-aturan kedisiplinan kelembagaan, seperti: 1) Harus ada aturan-aturan tentang kedisiplinan masuk jam kerja harus tepat waktu; 2) Kebersamaan: kita akan bisa menangani kegiatan kalau kebersamaan akan terjalin dengan baik antara teman pegawai, atasan dengan bawahan, begitupun sebaliknya, komunikasi, keakraban dan saling menghormati satu sama lain; 3) Memberikan keteladanan terhadap semua pegawai; 4) Memberikan jabatan fungsional umum; 5) Menciptakan suasana kerja yang kondusif penuh dengan kekeluargaan antar pegawai; 6) Meningkatkan kesejahteraan atau gaji pegawai; dan 7) Memberikan motivasi kepada pegawai melalui pembinaan, diklat, workshop, seminar, dll". (Wawancara Tanggal 13 Juni 2020)

Dari hasil wawancara yang dilakukan peneliti kepada Kepala Seksi Umum dan Kepegawaian Dinas PUPR Provinsi Sulbar (Ibu Sohra.Sos.M.si) mengatakan bahwa salah satu hal penting dalam suatu organisasi pemerintahan adalah memotivasi pegawai agar bekerja dengan giat untuk menggunkan seluruh jiwa dan karsanya dalammencapai tujuan organisasi.

'kita sangat mendorong agar para pegawai bekerja dengan baik, tetapi mereka butuh pemicu atau pendorong untuk bekerja. Kalau biasa-biasa saja hasilnya juga biasa-biasa. Karena itu ada beberapa hal yang penting dilkukan salah satunya adalah peran seorang pemimpin sebagai kepala instansi dalam mendorong para pegawainya bekerja dengan baik dan maksimal". (Wawancara 17 Juni 2020)

Di Dinas PU provinsi Sulbar dalam upaya untuk meningkatkan kinerja para pegawai maka ada beberapa hal yang mereka lakukan. Upaya-upaya tersebut sedemikian rupa dilakukan agar seluruh pegawai dapat meberikan kinerja terbaiknya. Menurut Kepala Dinas PUPR Provinsi Sulbar (Bpk.Ir.Muhammad Aksan,MT) salah satu bagian lain yang mereka lakukan adalah menjalin komunikasi yang baik dan intens antara pimpinan dengan para bawahan. 
"Mengenai komunikasi, kami selalu berkomunikasi dengan pegawai karena hal tersebut sangat penting apalagi menyangkut pelayanan. Komunikasi juga selalu kami lakukan melalui pertemuan-pertemuan rutin antar pegawai baik itu saat jam kerja maupun diluar jam kerja. Diluar jam kerja saya biasanya makan siang dengan beberapa pegawai, dengan begitu saya bisa berkomunikasi dengan cara yang berbeda, lebih rileks dan santai tanpa ada batasan mana pun antara pimpinan dan bawahan. Dengan adanya pertemuan tersebut maka hubungan saya dan bawahan terjalin dengan baik. Saya juga memberikan kesempatan kepada pegawai untuk memberikan masukan atau pendapat sehingga pegawai juga merasa dilibatkan". (Wawancara 13 Juni 2020).

Selain komunikasi dengan para pegawai dalam hal ini antara pimpinan dan bawahan, hal lain yang juga penting dalam rangka untuk menganlisis kinerja pegawai adalah pengarahan atau bimbingan yang diberikan kepada para pegawai. Berdasarkan hasil temuan peneliti dilapangan dari wawancara yang dilakukan kepada Kepala Dinas PUPR Provinsi Sulbar mengatakan bahwa sealam ini mereka proaktif memberikan pengarahan kepada para pegawainya seputar dengan tanggungjawab dan wilayah kerjanya.

"Dalam hal pemberian bimbingan dan juga pengarahan kepada bawahan / para pegawai kami selalu memberikan bimbingan dan juga pengarahan dalam menyelesaikan pekerjaaannya. Pengarahan itu biasanya berupa arahan lisan. Contoh arahan lisan, kami mengontrol secara langsung dan memberikan arahan-arahan yang semestinya dikerjakan oleh para pegawai agar mereka menyelesaikan pekerjaannya dengan baik. Dan Kami juga membimbing pegawai agar lebih kreatif dan produktif agar mereka bisa maju, kemajuan lembaga ditentukan oleh kinerja para pegawai itu sendiri di samping itu agarpara pegawai bersemangat dalam melaksanakan pekerjaanya, di sisi lain bahwa hakekat bekerja itu adalah dalam rangka Ibadah kepada Allah, Meletakkan pegawai pada posisi sesuai bidang dan keahlianya, karena kalau tidak sesuai bidang yang di mumpuni maka bisa menghambat dalam pekerjaanya". (Wawancara 13 Juni 2020)

Hal lainnya yang merupakan bagian dari anlisis kinerja pada penelitian ini adalah konsep situasi kerja yang dibentuk pemimpin. Berdasarkan wawancara kami dengan Kepala Dinas PUPR provinsi Sulbar (Bpk.Ir.H.Muhammad Aksan,MT) bahwa situasi kerja di Dinas PUPR tidak didesain secara khusus. Situasinya berjalan sesuai dengan kondisi kerja dilapangan.

"Sebenarnya kami tidak berperan sangat besar di dalam pembentukan situasi kerja di sini, karena memang situasi dan kondisi kerja yang nyaman dan kondusif telah terjalin di kantor ini sebelum kami datang. Mungkin hanya ada penambahan beberapa bagian, penambahan itu pun kami lakukan bukan karena kondisi kerja disini tidak nyaman, yang kami lakukan itu dimaksudkan hanya untuk mendekatkan diri secara personal antara kami dan orang-orang di kantor ini”. (Wawancara 13 Juni 2020).

Penerapan pengawasan yang optimal dan sanksi juga sangat dibutuhkan dalam rangka untuk mendorong kinerja para pegawai. Pengawasan dan pemberian sanksi akan menjadi salah satu cara dalammengontrol kinerja para pegawai di Dinas PU provinsi Sulbar. Berdasarkan hasil wawancara dengan Sekretaris Dinas PUPR Provinsi Sulbar (Bpk.Drs.Abdul halid aras) mengatakan bahwa:

"Mengenai pengawasan disini sudah menjadi tugas dan kewajiban kami selaku pimpinan, memberikan pengawasan kepada pegawai didalam menyelesaikan pekerjaannya. kami selalu memberikan hukuman kepada karyawan yang menyalahi aturan lembaga. Pengawasan ini biasanya langsung kami lakukan di tempat kerja dan pada saat jam kerja. Selanjutnya mengenai sanksi, Sanksi yang digunakan oleh pegawai PNS / Non PNS ini berupa: a. Sanksi peringatan (berupa peringatan tertulis); b. Sanksi administratif (berupa penurunan jabatan, denda atau ganti rugi); c. Sanksi skorsing (pemberhentian sementara); d. Sanksi pemutusan hubungan kerja (berupa pemecatan); dan e. Kalau khusus pegawai PNS sesuai dengan PP Nomor 53 tahun 2010 tentang Disiplin Pegawai Negeri Sipil bahwa ada 3 macam sanksi yaitu Hukuman disiplin ringan, sedang dan berat.

Dalam rangka untuk mewujudkan segala upaya dalam rangka mendorong para pegawai bekerja secara guna untuk menunjukkan prestasi kerja maka ada kendala-kendala yang dihadapi oleh pemimpin dilapangan. Hal tersebut diakui dari hasil wawancara dengan Sekretaris Dinas PUPR Provinsi Sulbar (Bpk.Drs.Abd. Halid Aras) bahwa:

"Berbicara tentang masalah dan kendala, kita semua pasti dihadapkan pada masalah- masalah dalam keseharian kita dalam hidup ini. Jadi dalam pemberian motivasi pastilah ada masalah dan kendala, baik itu dalam skala mayor ataupun minor, karena saya harus mengerti latar belakang dan motif pegawai itu dalam bekerja terlebih dahulu sebelum memberikan motivasi., dan memotivasi tiap orang akan berbeda caranya, seperti memotivasi orang yang memiliki skill akan lebih susah dari pegawai yang sedang-sedang saja, dan sebaliknya memotivasi pegawai tetap akan lebih mudah daripada memberi motivasi pada agen-agen di lapangan'. (Wawancara 13 Juni 2020)

Selanjutnya ketika penelti tanyakan seputar dengan apakah ada prosedur yang dilakukan di Dinas PU provinsi Sulbar dalam upaya untuk mendorong para pegawai dalam bekerja, mereka menyampaikan bahwa sifatnya arahan saja dalam bentuk lisan. Hal hasil wawancara dengan Kasubag Umum dan Kepegawaian Dinas PUPR Provinsi Sulbar (Ibu ST.Sohra.S.Sos.M.Si) yang mengatakan bahwa: 
"Sebetulnya yang kami lakukan bukan dibilang tahap atau prosedur karena memang sebenarnya dalam pemberian motivasi tidaklah susah jika para pegawai / para Kasi bersikap proaktif dalam bekerja, jadi kami hanya tinggal memanggil pegawai keruangan dan memberikan suntikan motivasi kepada mereka, terkadang kami juga membicarakan hal lain yang menjadi kesenangan para pegawai tersebut agar suasana tidak menjadi tegang. Kalau sedang tidak pada jam kerja kami juga memberikan motivasi kepada pegawai jika memang diperlukan, dan itu kami lakukan diluar kantor dan pada suasana informal yang mendukung untuk dapat respon yang baik dari pegawai". (Wawancara 13 Juni 2020)

Selain upaya-upaya tersebut diatas, menurut Kepala Dinas PU provinsi Sulbar bahwa mereka juga memberikan reward atau penghargaan kepada para pegawainya. Hasil wawancara dengan Kepala Dinas PU provinsi Sulbar menyebutkan bahwa:

"Menyangkut penghargaan, kami selalu memberikan penghargaan kepada para pegawai yang bekerja dengan baik dan memberikan kontribusi yang besar, karena dengan diberikannya penghargaan pegawai akan semakin termotivasi untuk meningkatkan semangat kerja. Adapun penghargaan itu berupa imbalan (reward), imbalan biasanya diberikan kepada pegawai yang sukses dalam melaksanakan: 1) Target-target lembaga; 2) Reward berbentuk tukin (tunjangan kinerja), kalau kinerjanya baik dan menghasilkan prestasi yang bagus maka tunjangan kinerja akan di tambah, begitu sebaliknya jika kinerja menurun, tidak sesuai yang diharapkan maka tunjangan kinerja akan dikurangi, sesuai kinerja masing-masing pegawai; 3 ) Pegawai yang disiplin akan diberi hadiah, begitu sebaliknya jika pegawai sering terlambat akan di kenai sanksi; 4) Jika satu menit terlambat, dikurangi setengah persen tunjangan kerja (disiplin); 5) dengan memberikan penghargaan berupa satya lencana pengabdian selama 10 tahun, 20 tahun dan 30 tahun, dan kami juga mengadakan outbound". (Wawancara 13 Juni 2020)

Setelah diberikan stimulus seperti yang telah disebutkan diatas maka selanjutnya adalah apa umpan baliknya kepada instasi PUPR. Apa memeberikan dampak yang diharapkan. Dari hasil wawancara dengan Kepala Dinas PUPR Provinsi Sulbar (Bpk.Ir.H.Muhammad Aksan,MT) mengatakan bahwa:

"Pada dasarnya setiap motivasi yang kami berikan untuk bawahan selalu berujung pada diri mereka sendiri keberhasilannya, selain memang ada faktor cara-cara memberikan dorongan, tetapi semua itu bergantung dari kemampuan dari setiap pegawai untuk menerima dorongan dan menjadikannya sebagai sebuah motivasi membangun untuk memperbaiki kinerja dan performa mereka. Karena dalam kenyataannya ada pegawai yang tidak mampu mentransformasi dorongan yang diberikan itu menjadi suatu kritik yang membangun, tetapi para pegawai disini selalu baik dalam menyikapi motivasi yang kami berikan". (Wawancara 13 Juni 2020)

Sistem Penempatan Pegawai Dinas Pekerjaa Umum dan Perumahan Rakyat Provinsi Sulawesi Barat

Sumber daya manusia memiliki posisi sangat strategis dalam organisasi. Maksudnya adalah unsur manusia memegang peranan penting dalam melaksanakan aktivitas dalam mencapai tujuan. Untuk itulah eksistensi sumber daya manusia dalam organisasi sangat kuat. Untuk mencapai kondisi yang lebih baik maka perlu adanya manajemen sumber daya manusia secara memadai sehingga terciptalah sumber daya manusia yang berkualitas, loyal dan berprestasi.

Manajemen sumber daya manusia merupakan usaha untuk mengarahkan dan mengelola sumber daya manusia di dalam lembaga khusunya di Dinas PUPR Provinsi Sulbar agar mampu berfikir dan bertindak sebagaimana yang di inginkan oleh lembaga tersebut. Adapun upaya Kepala Dinas PUPR provinsi Sulbar dalam mengelola manajemen sumber daya manusia dalam meningkatkan kualitas SDM pegawai di lingkungan Dinas PUPR Provinsi Sulbar adalah sebagai berikut: 1) Melakukan perencanaan sumber daya manusia yang baik; 2) Penarikan sumber daya manusia (recruitmen); 3) Seleksi; 4) Pelatihan dan pengembangan; 5) Penilaian prestasi kerja; 6) Kepuasan Kinerja Pegawai; 7) Kesejahteraan Pegawai; 8) Penciptaan Dan Pembinaan Hubungan Kerja Yang Efektif.

Dari hasil penelitian diperoleh bahwa kepemimpinan di Dinas PUPR Provinsi Sulbar memberikan pengaruh besar dalam mengelola manajemen sumber daya manusia dan kepemimpinan di Dinas PUPR Provinsi Sulbar cukup baik. Alasan yang memberikan kriteria "cukup baik" adalah karena keterlibatan langsung kepala Dinas PUPR Provinsi Sulbar dalam memotivasi dan melakukan kreasi dalam melaksanakan pengorganisasian organisasi.

Dari urian diatas jelaslah bahwa pelaksanaan peningkatan kinerja pegawai mempunyai arti penting bagi setiap instansi pemerintahan maupun swasta karena kepemimpinan akan memberikan pengaruh terhadap kemampuan kerja. Hal itu sangat erat pengaruhnya karena makin baik strategi pelaksanaan peningkatan sumber daya manusia makin meningkat pula kinerja pegawai, hal ini dapat dilihat dari hasil penelitian bahwa cukup baik pelaksanaan peningkatkan sumber daya manusia organisasi pada Dinas PUPR Provinsi Sulbar.

Dari hasil yang demikian, berarti peranan pemimpin di Dinas PUPR Provinsi Sulbar telah melakukan perannya dalam berkomunikasi, mengarahkan dan memberikan bimbingan, perannya dalam memotivasi, pembentukan situasi dan iklim kerja yang kondusif, pemberian pengawasan dan hukuman, mengetahui kendala-kendala dalam memotivasi serta cara-cara mengatasi permasalahan yang timbul dalam pemberian motivasi.

Berdasarkan hasil analisis yang dilakukan oleh peneliti dapat diketahui kendala-kendala yang di hadapi pemimpin dalam memotivasi pegawainya yaitu setiap 
pegawai mempunyai tipe dan karakter yang berbeda-beda dari setiap orang. Upaya memotivasi pegawai agar memiliki skill memang lebih sulit dibanding pegawai yang biasa-biasa saja. Hal tersebut dikarenakan tingkat dan pola pikir mereka berbeda antara pegawai yang satu dengan yang lain.

Mengatasi permasalahan dalam memotivasi, seorang pemimpin lebih meningkatkan hubungan personal dengan para pegawainya. Dalam pendekatan ini akan terjalin sebuah hubungan yang berkesinambungan antara semua pegawai maupun karyawan. Memahami karakter dan kepribadian setiap pegawai akan memudahkan untuk memberikan motivasi.

Kemampuan kepemimpinan dalam meningkatkan kinerja pegawai di lembaga ini mempunyai peran sangat penting. Hal tersebut dikarenakan dengan motivasi yang tinggi, maka pekerjaan (tugas) dilakukan dengan bersemangat dan bergairah, sehingga akan dicapai hasil yang optimal (kinerja tinggi) yang tentunya akan mendukung tercapainya tujuan yang diinginkan dengan efisien dan efektif.

Motivasi berkaitan dengan kepuasan dan kinerja, dimana kepuasan dan kinerja hanya dapat ditingkatkan dengan motivasi yang tinggi, kemauan dan kemampuan dalam melakukan tugas yang didukung dengan lingkungan kerja yang nyaman.

Jadi dari semua penjelasan diatas dapat diketahui bahwasannya kemampuan kepemimpinan dapat meningkatkan kinerja pegawai di Dinas PUPR Provinsi Sulbar. Hal tersebut ditunjukkan dengan adanya pegawai selalu disiplin, tepat waktu dalam bekerja, aturan-aturan dari pemimping sangat tegas, di sisi lain bisa dikatakan pemimpin mempunyai sifat yang lemah lembut, santun terhadap pegawainya, mengayomi, mengakrabi terhadap bawahan, tidak pilih kasih semua jabatan di anggap sama, sering menyapa dan rasa kebersamaan menjadi menyatu di lingkungan Dinas PUPR Provinsi Sulbar.

Dengan demikian para pegawai menjadi sangat antusias terhadap kinerjanya, kadang merasa sungkan terhadap pimpinanannya, karena terlalu baik terhadap bawahaanya. Sehingga situasi kerja sangat mendukung dan dapat menghasilkan capaian kinerja yang diharapkan sesuai dengan visi organisasi.

Sistem Kerja Pegawai Dinas Pekerjaan Umum dan Perumahan Rakyat Provinsi Sulawesi Barat

Berdasarkan hasil analisis kinerja di Dinas PUPR Provinsi Sulbar berkaitan dengan sistem kerja para pegawai di Dinas PUPR Provinsi Sulbar maka beberapa hal yang penting menjadi perhatian, yaitu:

1) Harus ada aturan-aturan tentang kedisiplinan masuk jam kerja harus tepat waktu. Misalnya: masuk kantor jam 07.30 WIB s/d 15.OO WIB, jika ada pegawai yang sering datang terlambat dikenai sanksi, mulai dari sanksi ringan, sedang dan berat.

2) Kebersamaan: kita akan bisa menangani kegiatan kalau kebersamaan akan terjalin dengan baik antara teman pegawai, atasan dengan bawahan, begitupun sebaliknya, komunikasi, keakraban dan saling menghormati satu sama lain.

3) Memberikan keteladanan terhadap semua pegawai, maksudnya ketika kita menyuruh pegawai untuk disiplin, maka mereka mau melaksanakan dan meningkatkan kinerja yang lebih efektif dan efisien.

4) Menciptakan suasana kerja yang kondusif penuh dengan kekeluargaan antar pegawai dan Menciptakan rasa kekeluargaan, membangun yang tinggi artinya secara internal di dalam ataupun di luar kantor, pertemuan-pertemuan / insiden yang membuat nyaman, walupun tidak pernah ketemu dalam menjalankan tugas tertentu di luar kantor, maka dari itu dengan berkumpul, makan bersama, silaturahim yang menjadi penting.

5) Meningkatkan kesejahteraan atau gaji pegawai.

6) Memberikan motivasi kepada pegawai melalui pembinaan, diklat, workshop, seminar, dll.

7) Pendekatan religius, artinya disentuh hatinya, melalui pendekatan agama, apa yang dilakukan ini tidak lepas dari nilai ibadah kepada Allah SWT, karena sebuah kebutuhan beriman.

Berdasarkan hasil penelitian menunjukkan kinerja pegawai salah satunya dipengaruhi oleh kemampuan kepemimpinan kepala instansi Dinas PUPR Provinsi Sulbar. Kepemimpinan khususnya dalam peningkatan sumber daya manusia belum terlaksana secara maksimal dan dari hasil analisa atas rencana strategi. Hal ini disebabbkan karena tidak ada rencana aksi untuk merealisasikan tindakan- tindakan peningkatan kinerja pegawai tersebut cenderung sebatas wacana. Seharusnya dalam merencanakan harus seimbang dan berjalan sesuai tupoksi yang sudah direncanakan. Sedangkan sebaikbaiknya strategi harus ditunjukkan melalui aksi dan tindakan dengan perencanaan aksi yang jelas sebelumnya.

Kepemimpinan merupakan aspek kemampuan manajerial dan seni dalam memberikan pengaruh kepada orang lain untuk mengkoordinasikan pekerjaan secara tepat dan cepat, termasuk pengambilan keputusan dan penentuan prioritas. Dalam hal strategi kepemimpinan Kepala Dinas PUPR Provinsi Sulbar melakukan beberapa hal pokok perencanaan sehubungan dengan usaha meningkatkan kinerja pegawai yaitu perencanaan tentang aturan kerja yaitu dengan memperhatikan asumsi terhadap kemungkinan-kemungkainan yang mana suatu kondisi perlu kerja ekstra akibat tingginya permintaan.

Hasil penelitian tersebut menunjukkan bahwa dalam menetapkan aturan strategi, Kepala Dinas PU provinsi Sulbar hanya memberikan aturan dengan garis besar ukuran kerja yang harus diselesaikan. Kepala Dinas PUPR Provinsi Sulbar juga menjalankan tugas untuk memotivasi terhadap pegawainnya agar memiliki dedikasi atas pekerjaannya. Bentuk motivasi adalah dengan memberikan insentif berdasarkan jumlah pekerjaan. Maka dari itu segala hambatan yang ditemui dapat di lakukan penanggulangan secara baik dengan memilih alternatif lain agar tercapainya pelaksanaan 
Hasil penelitian di atas menunjukkan bahwa, jelaslah bahwa kemampuan kepemimpinan yang dimaksud disini merupakan sarana yang digunakan untuk memperoleh kesuksesan atau keberhasilan dalam mencapai tujuan akhir atau sasaran.

\section{KESIMPULAN DAN SARAN}

Kesimpulan hasil penelitian ini bahwa kemampuan kepemimpinan dalam meningkatkan kinerja pegawai di Dinas PUPR Provinsi Sulbar diperlukan dalam rangka untuk menunjang kinerja pegawai. Peran Pemimpin dalam Mengelola Sumber Daya Manusia di antaranya: pemimpin sebagai motivator, sauri teladan, instruktor, sahabat, trutor, penggiat, pengayom, dan pendidik. Peranan pemimpin dalam pemberian pengawasan, sebaiknya menjadi perhatian penting sehingga pegawai dapat meningkatkan kedisiplinan dalam menyelesaikan pekerjaannya.

\section{DAFTAR PUSTAKA}

Ambar T. Sulistiyani dn Rosidah. 2003. Manajemen Sumber Daya Manusia. Cetakan Pertama. Penerbit Graha Ilmu. Yogyakarta

Bilson, Simamora. (2003). Panduan Riset Perilaku Konsumen. Surabaya: Pustaka Utama.

Dharma, Surya. (2005). Manajemen Kinerja Falsafa Teori dan Penerapannya. Pustaka Belajar. Jakarta.

Hasibuan, Malayu. (2012). Manajemen Sumber Daya Manusia. Bumi Aksara. Jakarta.

Irawan, Basu Swastha. (2000). Manajemen Pemasaran Modern. Edisi 2. Liberty. Yogyakarta.

Karyadi, M.. 1989. Kepemimpinan. Bandung: Karya Nusantara.

Nur, M., Nurkaidah, N., \& Nonci, N. (2020). Gaya Kepemimpinan Dan Sumber Daya Manusia Terhadap Kinerja Pegawai Pada Kantor Sekretariat Daerah Kabupaten Majene. Jurnal Paradigma Administrasi Negara, 2(1), 24-31.

Peraturan Pemerintah Nomor 101 Tahun 2000 tentang Pendidikan dan Pelatihan Jabatan Pegawai Negeri Sipil

Peraturan Pemerintah Nomor 30 Tahun 2019 tentang Penilaian Kinerja Pegawai Negeri Sipil (PNS),

Sudarmanto, Kinerja dan Pengembangan Kompetensi SDM, Yogyakarta: Pustaka Pelajar, 2009.

Sondang P. Siagian, Manajemen Sumber Daya Manusia, Jakarta: PT Bumi Aksara, 1999

Undang-Undang Nomor 5 Tahun 2014 tentang Aparatur Sipil Negara (ASN).

Undang-Undang Republik Indonesia Nomor 25 Tahun 2009 tentang Pelayanan Publik. 